\title{
Deuteronômio e Mishná: tradições que se unem na defesa dos pobres $\left(1^{\circ}\right.$ Parte)
}

\author{
Antonio Carlos Frizzo ${ }^{1}$
}

Passados 45 anos, não resta dúvida de que o Concílio Vaticano II (19621965) foi o segundo pentecostes vividos pelas igrejas cristãs em todo o mundo. Ele, não somente ajudou-nos a ver e a compreender os sinais dos tempos, como bem alertou-nos seu expoente e incentivador, papa João XXIII, como aproximou tradições religiosas na edificação de um mundo mais fraterno.

Desde a publicação da declaração Nostra Aetate, 28 de outubro de 1965, a teologia cristã católica aprimora seu relacionamento com a tradição judaica. Nesse espaço de tempo, o diálogo e experiência ecumênica testemunham inúmeros esforços. Do lado católico sobra exemplos que "reconhece que os primórdios da fé e de sua eleição já se encontram nos Patriarcas, em

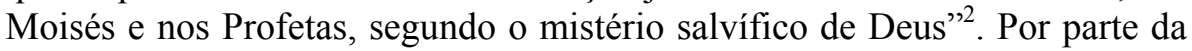
tradição judaica os esforços são correspondentes. Basta comprovar a série de trabalho que culminou com a declaração "Dabru emet" (Falai a verdade: Zc $8,16)$, assinada por 172 personalidades do mundo judaico ${ }^{3}$.

\footnotetext{
${ }^{1}$ Este texto eu dedico ao professor e amigo Dr. Emanuel Bouzon (in memorian). Com ele, em encontros semanais, entre idas e vindas à cidade do Rio de Janeiro, nos anos de 2004-2005, para cumprir exigências acadêmicas junto ao Departamento de Pós-graduação da PUC-Rio, descobri que os textos bíblicos sempre inspiram novas concepções sobre יהוה אחד (Adonai é Um).

${ }^{2}$ NT 4.

${ }^{3}$ A integra da declaração está publicada na Revista TQ, 15, 2009, pp. 132-136. Aceno ao trabalho do professor Nachman Falbel sobre o tema Leitura da Bíblia no Judaísmo. Com a maestria que lhe é peculiar, o brilhante mestre balisa, considerando a Torá Oral e Escrita, o modo de fazer leitura bíblica na tradição judaica. Cf. FALBEL, N., Leitura da Bíblia no Juda-
} 
Neste artigo são aproximados dois universos literários. Com base nos textos selecionados do livro do Deuteronômio, com explicita citação à trilogia social: estrangeiro, órfão de viúva (Dt 10,12-22; 14,28-29; 16,9-12; $24,17-22 ; 26,12-15 ; 27,11-26)$ procuramos perceber o grau de importância que este universo jurídico teve na elaboração das leis expressas na Mishná, pelos sábios tanaítas. São abordados, em comparação aos textos deuteronômios, somente quatro tratados: colheita, dias festivos, sobre os votos e relações econômicas.

$\mathrm{Na}$ forma em que chegou até nossos dias, a Mishná está dividida em seis principais ordens. Cada ordem, intitulada (seder, no plural sedarim), contém certo número de tratados. No total, são 63 tratados que se dividem em capítulos, chamado de peraquim. Nos capítulos encontramos sentenças, regras ligadas ao comportamento social, intituladas mishnayyot. Cada uma dessas sentenças recebe o nome de mishná .

Ao longo de toda sua existência, as comunidades religiosas de Israel, espalhadas nos mais diferentes centros de produção literária, sempre estiveram sob um determinado poder imperialista ${ }^{5}$. Este pequeno país, por sua posição geopolítica, enfronhado entre grandes potências regionais, sempre recebeu influência dos movimentos políticos e literários de além fronteiras. Os projetos políticos, movimentos de revoltas ou contra as reformas, as relações econômicas, ofereceram elementos dos mais variados tipos à elaboração teológica, presentes nas páginas bíblicas. Impérios e produções literárias se interagem.

ísmo, em: Hermenêuticas Bíblicas: Contribuições ao I Congresso Brasileiro de Pesquisa Bíblica, REIMER, H. e DA SILVA, V. (orgs.), São Leopoldo, Oikos; Goiania, UCG, 2006.

${ }^{4}$ Para o público iniciante no estudo das tradições judaicas existem obras significativas. Destaco: STRACK, H. L e STEMBRGER, G., Introduccion a la literatura talmúdica y midrásica. Valencia, Institución San Jerónimo para la Investigación Bíblica, 1989; SCARDELAI, D., Da religião bíblica ao judaísmo rabínico. São Paulo, Paulus, 2008. Em espanhol é possível encontrar a edição crítica e completa da Mishná editada por Carlos del Valle, Salamanca, Ediciones Sigueme, 1997.

${ }^{5}$ Consideram-se, principalmente os impérios Babilônico, Persa, Grego e Romano, por serem amplamente documentados, quer nos textos bíblicos quer em textos extra bíblicos. Cf. JOANNÈS, F., La vie de déportés de Juda en Babylonie. In: LMB, 161, 2004, pp.27-31; SCHWARTZ, J., Quelques réflexions à propor de trois catastrophes. In: DAHAN, G. (Org.), Les Juifs au regard de l'histoire, Paris, Picard, 1985, pp. 21-29. SCHWANTES, M., Sofrimento e esperança no exílio: história e teologia do povo de Deus no século VI a.C. São Leopoldo, RS, Oikos, 2007. No tocante Israel em meio as forças imperialista oportuno conferir o trabalho de Léon Epsztein: A justiça social no Antigo Oriente Médio e o povo da bíblia. São Paulo, Paulinas, 1990. 


\section{A tradição judaica em meio à experiência da הלָ̣ia, "desterro"}

Ao longo de toda sua existência, as comunidades religiosas de Israel, espalhadas nos mais diferentes centros de produção literária, sempre estiveram sob um determinado poder imperialista ${ }^{6}$.

O cenário dominado pela presença romana ocupa o centro de todo o trabalho de compilação e redação da Mishná. É durante a presença desse imperialismo brutal que tem início o processo redacional da tradição oral, culminando com a Mishná. Logo após a conquista romana da cidade de Jerusalém, com a destruição do II Templo, em 70 d.C., e que persistiu por mais de dois séculos, os sábios judeus, exatamente em Yavneh (Jâmnia), procuravam responder aos desafios impostos sem, no entanto, menosprezar as máximas bíblicas.

A pujança da cidade de Jerusalém, somada às classes sacerdotais e funcionários envolvidos nos trabalhos da corte e do templo, muito servis às normas ditadas por Roma, não serão capazes de impedir a dispersão de parte da população das cidades mais importantes de Israel, diante das políticas efetuadas pelos imperadores romanos. $\mathrm{O}$ regime imposto pelos romanos se apresentou como um poderio avassalador. Os anos seguintes a 66 nada mais representam à comunidade judaica, dentro e fora das terras de Israel - um sinônimo de destruição em massa. A conjugação de forças, motivadas por líderes religiosos como R. Yohanan b. Zakai, R. Akiba, R. José b. Halafta terá um caráter de nobre resistência. Pois, sabe-se que nem todos os grupos religiosos se uniram contra a dominação romana. Os fariseus, por exemplo, não foram favoráveis a qualquer tipo de movimento insurrecional, preferindo apegar-se à leitura e estudo da Lei; é a eles que devemos o surgimento do judaísmo sobre a forma do rabinismo.

Sempre envolta com as grandes mudanças políticas do cenário internacional", a compreensão da experiência do termo iç̣:a, "exílio, desterro",

\footnotetext{
${ }^{6}$ Consideram-se, principalmente os impérios Babilônico, Persa, Grego e Romano, por serem amplamente documentados. Cf. JOANNÈS, F., La vie de déportés de Juda en Babylonie. In: LMB, 161, 2004, pp.27-31; SCHWARTZ, J., Quelques réflexions à propor de trois catastrophes. In: DAHAN, G. (Org.), Les Juifs au regard de l'histoire, Paris, Picard, 1985, pp. 21-29.

7 "Por ser um corredor comercial, ligando o Egito com a Fenícia, o Norte da Síria, a Mesopotâmia e a Arábia, a terra de Israel sempre despertou o interesse dos grandes impérios: egípcios, assírios babilônicos, persas, gregos, romanos". MARQUES, M. A., Beleza, sedução e morte: uma leitura exegética de Judite 16,1-12. Tese de doutorado no Programa de PósGraduação em Ciência da Religião, Universidade Metodista de São Paulo, 2008, p. 201. Destaque para o capítulo III, na seção sobre o "o grupo dos hasidim", pp. 221-226.

${ }^{8} \mathrm{O}$ verbo grego $\delta\llcorner\alpha \sigma \pi \varepsilon i ́ p \omega$, "dispersar", está na raiz da palavra diáspora, presente na LXX e oriundo do III século a.C. Sob o pressuposto de dispersar, distribuir, disseminar foi possível empregar o conceito de diáspora às comunidades espalhadas em diversas localidades fora das
} 
acompanhou todas as fases históricas vivenciadas pela comunidade religiosa de Israel. Tal experiência pode ser verificada com clareza ao longo de inúmeras produções literárias ocorridas em Israel. Produções essas, que colaboraram na garantia da identidade e perspectivas de verdadeira sobrevivência ao longo de toda sua existência. $\mathrm{O}$ fenômeno Israel não se compreende fora dos textos sagrados produzidos pela comunidade. Eis um fator essencial na preservação da identidade de Israel, em meio aos grandes confrontos do cenário militar e cultural impostos pelos dominadores. Apaziguadas as armas é preciso conter o domínio cultural.

Na composição da Mishná, a experiência da diáspora envolve todos os fatores da vida social, religiosa e cultural dos judeus. O processo de compilação dos textos da Mishná coincide com o período de ocupação do império Romano ${ }^{9}$. Os planos desse avassalador império colocaram em risco a identidade ética das comunidades religiosas de Israel. Embora residindo em terras

terras de Israel. Segundo os textos bíblicos, o senso de ser estrangeiro, de viver em terras alheias, muito cedo foi experimentado pelos patriarcas (Gn 15,13; 23,4). A produção literária dos primeiros profetas, tidos como escritores, irá evidenciar as realidades históricas que submetem as comunidades de Israel à condição de estrangeiro. No uso do termo conceito גוּז "desterrados" será desenvolvido as visões proféticas que visam o restabelecimento, em terras de Israel, da porção dos exilados na Babilônia e daqueles que permaneceram em Israel. A

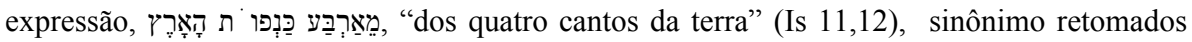

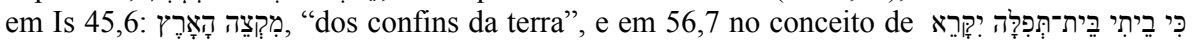

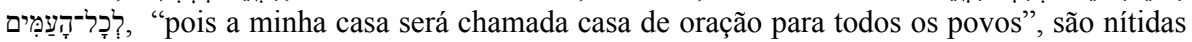
referências às comunidades que vivem fora dos limites geográficos de Israel. Tais expressões soam como um autêntico projeto social de reconstruir uma nação espalhada pela dominação babilônica. O profeta Jeremias é outro que se utiliza de conceitos específicos ao expor o ideal

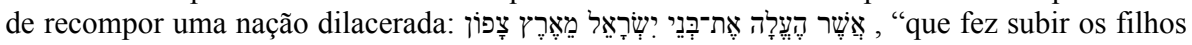
de Israel da terra do norte" (Cf. Jr 16,15. 23,8). Nota-se que a palavra diáspora, de modo

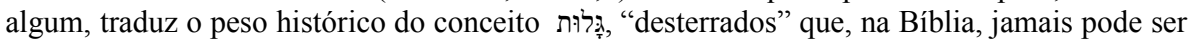
entendida como algo abstrato quando se refere ao exílio, aos errantes, aos escravos ou ainda a um tempo de alienação. Cf. PAUL, A., Une voie d'approche du fait juif: diaspora et gālût. In: CARREZ, M.; DORÉ, J.; GRELOT, P. (Orgs.), De la Tôrah au Messie, Paris, Desclée, 1981, pp. 367-380. Segundo Manns, o conceito diáspora tornou-se uma realidade histórica junto às comunidades judaicas. Sua síntese apoia-se nos informes bíblicos e nos escritos de Flávio Josefo. Cf. MANNS, F., Le Judaïsme: milieu et memoire du nouveau testament, Jerusalém, Franciscan Printing, 1992, pp. 208-218; HORSLEY, R. A., Jesus e o Império: o reino de Deus e a nova desordem mundial, São Paulo, Paulus,2004, p. 22.

${ }_{9}$ Propícia a observação de Schwartz feita sobre as comunidades religiosas atingidas no percurso das três guerras envolvendo romanos e judeus: "O primeiro embate contra Roma se limitou à Terra Santa. O segundo, nascido de longo ressentimento, atingiu mais nitidamente a Diáspora, se bem que as forças não foram suficientes para impedir a terceira. A revolta, no final do reinado de Adriano, atingiu, em certos aspectos, o pivô da primeira revolta. E foi assim que o II século d.C. presenciou o desaparecimento de uma cultura de forma grega e a conclusão, na Judéia, do desastre largamente iniciado em 70 d.C.”. Cf. SCHWARTZ, J. $\grave{A}$ propôs de trois catastrophes, op.cit., p. 29; MANNS, F., op. cit., pp. 35-38. 
de Israel, ou além fronteira, as comunidades, na época dos Tannaítas ${ }^{10}$, não perderam de vista o projeto maior de viver, em meio às contradições históricas e sociais impostas pela política imperialista, o seguimento dos trâmites expostos nos textos sagrados.

A Mishná é o resultado final de um processo redacional, no qual os sábios de Israel não mediram esforços para compilar, por meio de um esmerado trabalho, sempre pautado pela desenvoltura no conhecimento da Torá escrita e oral, concluído em meados do ano 219 d.C. ${ }^{11}$. A Torá exige um constante processo de renovação. Tal movimento está dividido entre a pesquisa (Midrash) e o estudo-ensino (Talmud). Ao redigir a Mishná, os sábios atingem um dos estágios desse processo de renovação da Torá ${ }^{12}$. O conhecimento do passado se justifica numa harmonia e coerência com as máximas divinas. Urge ensinar o passado, tendo em vista o futuro.

A compreensão do conceito de Torá se divide em dois aspectos que se completam mutuamente. O termo clássico "Tợ "Tơ oral" usado pela tradição judaica é considerado antigo na moderna literatura ${ }^{13}$. No outro

\footnotetext{
${ }^{10}$ Nome usado para identificar a primeira geração de sábios que se debruçou sobre a interpretação da Torá. São identificados seis gerações de sábios, entre os anos 20 a 200 d.C. A geração seguinte leva o nome de amoraítas (220 - 500 d.C.)

${ }^{11}$ A abordagem é consensual entre inúmeros estudos. Verifica-se que os fatos ocorridos em meados do ano 135, impuseram à organização rabínica novas exigências. Como bem analisam Strack e Stemberger: "O redator colecionou as fontes, selecionou as leituras mais importantes..., transmitiu assim o texto eclético a partir dos treze modos de halakhah como havia aprendido". STRACK, H. L. e STEMBERGER, G., Introducción a la literatura talmúdica y midrásica,Valencia, Soler, 1989, p. 202; Cf. KÜNG, H., Ebraismo, Milano, RCS, 2005, p. 160. Uma ressalva histórica feita por Miranda e Malca facilita compreender o surgimento da Mishná: "O cristianismo não se expandiu e o judaísmo rabínico não se consolidou nos vazios de um Império decadente ou de uma civilização em perigo, como muitos miticamente acreditam. No que se refere ao cristianismo, foi diante de um mundo no melhor de sua forma que ele teve, desde o início, de apresentar também o melhor de si mesmo para garantir sua expansão e sua consolidação, como ilustra toda a literatura patrística. Quando o Nassi Shimon morreu e sucedeu-lhe seu filho Iehudá Hanassi, nos finais do século II d.C., a liderança palestina dos judeus cresceu de forma significativa. A posição social, a cultura, as habilidades de organizador e qualidades de estadista e de devoção fizeram de Iehudá um dos homens mais extraordinários de sua época. Até hoje é referido como "O Príncipe", "Nosso Santo Rabino" ou simplesmente "Rabi". Sob sua orientação foi compilado e organizado o código de leis, a Mishná”. DE MIRANDA, E. E., e MALCA, J. M. S., Sábios Fariseus: reparar uma injustiça, São Paulo, Loyola, 2001, p. 51; Cf. COHEN, A., Le Talmud, Paris, Payot, 1986, p. 32. Horsley declara ser a Mishná "o fruto mais notável da atividade rabínica". Cf. HORLEY, R. A., Arqueologia histórica e sociedade na Galiléia, São Paulo, Paulus, 2000, p.166.

${ }^{12}$ Cf. Ibidem, p. 64.

${ }^{13}$ Uma boa definição pode ser encontrada nos trabalhos de Safrai. Na sua opinião, deve-se ter certa precaução diante do entendimento dado à palavra torá. Na bíblia hebraica, o conceito básico dessa palavra é "instrução", mas pode receber também um significado mais amplo sendo compreendida na sua forma plural: torot, ensinamentos, leis. Cf. SAFRAI, S., Oral
} 


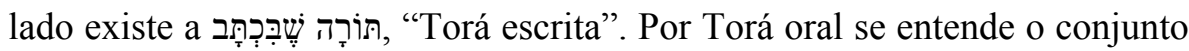
de normas estabelecidas pelos sábios e fielmente transmitidas na relação mestre e discípulo. Assim, deixa transparecer o primeiro parágrafo do tratado Pirkei Abhot:

\begin{abstract}
"Moisés recebeu a Torá no Sinai e a transmitiu a Josué, Josué aos anciãos, os anciãos aos profetas, os profetas a transmitiram aos homens da Grande Assembléia. Estes diziam três coisas: sede cauteloso no julgamento, fazei muito discípulos, colocai uma proteção em torno da Torá" ${ }^{14}$.
\end{abstract}

Tais normas formam a jurisprudência rabínica que recebe o nome de הלכה, halakhah. Aos sábios ${ }^{15}$, por meio de uma autoridade ilimitada, coube a missão de interpretar a Torá e garantir a execução dos princípios das halakhoth. Tais normas, englobando todos os aspectos da vida pessoal e comunitária, enfocavam princípios como: nascimento, casamento, normas no trabalho na agricultura, preceitos éticos e teológicos ${ }^{16}$.

O termo Torá implica duas diferentes conotações, compreensões. Torá significa o trabalho de ensinar os mandamentos de YHWH e incentivar o cumprimento das leis. Não há um grau hierárquico ao relacionar a oralidade ao escrito. A diferença está no processo e não no valor de credibilidade ou divergência de conteúdo.

Tora. In: SAFRAI, S. e TOMSON, P. J. (Orgs.) The literature of the Sages, Philadelphia, Van Gorcum, Assen/Maastricht, 1987, pp. 35-119.

${ }^{14}$ Cf. Abot 1,1. DEL VALLE, C., (Ed.), La Misna, Salamanca, Sígueme, 1997, p. 837.

${ }^{15}$ A compreensão de Torá, como texto sagrado, doado por Deus a Israel, por meio de Moisés, compreende sempre uma atualidade, aos desafios e problemas no hoje da existência humana. Nessa função de atualizar os conceitos divinos, está a função dos sábios. No tratado BQ (Babá qammá) 5,7 encontramos a seguinte afirmação, que justifica o conceito atual, em relação aos textos sagrados: "Porque a Escritura fala de casos presentes e comuns". Essa compreensão transforma a jurisprudência não numa norma presa a um passado, mas inserida no universo de uma comunidade sempre em transformação. Útil a citação de Urbach, ao recorrer à uma visão de Santo Agostinho, alheio ao mundo cultural judaico, para enfatizar o apego incondicional à tradição e ao exercício dos sábios, em meio aos desafios da comunidade religiosa: "É uma verdade surpreendente que o povo judeu jamais abandonou suas leis, seja sob as normas dos reis pagãos ou sob a dominação dos cristãos. Neste aspecto, ele se distingue das outras tribos e nações. Não houve nem imperador, nem rei que, os encontrando dentro de seu país, fosse capaz de impedir os judeus de se separarem, pela observância de sua Lei, do resto da família dos outros povos". Cf. URBACH, E. E., Les sages d'Israël: conceptions et croyances des maîtres du Talmud, Paris, Cerf-Verdier, 1996, p. 541. Ver também a análise de Briend sobre a vida das comunidades, privadas do templo, em terras da Babilônia. BRIEND, J., Une communauté juive sans temple. In: LMB, 161, 2004, pp. 33-35.

${ }^{16}$ Sobre todos os tratados na Mishná, vale conferi-los mais adiante, quando oportunamente analisam-se os respectivos textos mishnáícos relacionando-os ao livro do Dt. 


\begin{abstract}
"Rabban Yohanan ben Zakkai, com seus colegas e seus discípulos, começou a reconstruir a vida judaica sob a Palavra de Deus, na Torá. A Torá, para os fariseus não é somente a Escritura (Torá escrita); ela é também e sobretudo tradição (Torá oral)"'17.
\end{abstract}

Os inúmeros percalços provocados por constantes guerras e violações de direitos é a causa maior do desencadeamento do processo redacional imposto às leis orais. Pode-se imaginar que, se não fosse essas últimas realidades cercearem a vida da comunidade religiosa, não existiria, em seu formato atual, os textos da Mishná, e o exercício da oralidade seria corrente, ainda, em nossos dias.

\title{
A autoridade hermenêutica de Rabi Hillel
}

Separados por milhares de quilômetros e vivendo sempre sob os mesmos domínios imperialistas ${ }^{18}$, as comunidades judaicas instaladas na região do Eufrates jamais se distanciou culturalmente da cidade de Jerusalém ${ }^{19}$. Sabe-se que os judeus manifestavam sua pertença ao templo de Jerusalém enviando, periodicamente, a quantia correspondente dos frutos armazenados durante a colheita, no cumprimento dos preceitos. Fala-se de caravanas formadas por milhares de pessoas em marcha pelo deserto da Síria, com etapas em Palmira, Damasco e Bashan em direção ao monte Sião ${ }^{20}$.

Seguindo a informação de Charlesworth, Hillel, cognominado "o velho", ou "o babilônico", fez seus primeiros estudos sobre a Torá em sua terra natal, Babilônia. Nasceu no ano 60 a.C. vindo a falecer em 20 d.C., vivendo sob as políticas empreendidas por Herodes, o grande (37 - 4 a.C), sendo

17 Cf. LENHARDT, P., "La valeur des sacrifices dans le judä̈sme d'autrefois et d'aujourd 'hui”. In: NEUSCH, M. (Org.), Le sacrifice dans les religions, Paris, Beauchesne, 1994, p. 62.

${ }^{18}$ Manns apresenta uma síntese sobre os vários impérios e suas respectivas políticas frente às comunidades judaicas. Cf. MANNS, F., Le judaisme: milieu et mémoire du Nouveau Testament, op. cit., pp.25-40.

${ }^{19}$ Salutar conferir as cidades babilônicas, bem como, suas características nos anos que seguiram o exílio babilônico. Cf. STEINSALTZ, A., The Talmud: the Steinsaltz edition, op. cit., pp. 27-28.

${ }^{20}$ Cf. HADAS-LEBEL, M., Hillel: un sage au temps de Jésus, Paris, Albin Michel, 2005, p. 18. Ao descrever sobre a importância do "concílio" de Yabné e seu esforço em determinar os livros canônicos ou não, Manns destaca que o crivo hermenêutico adotado considerou as regras estabelecidas por Hillel. Cf. MANNS, F., op. cit., p.41. 
contemporâneo de Jesus de Nazaré ${ }^{21}$. Não se sabe exatamente quando passou a residir em Jerusalém no desejo de completar seus estudos, tendo como diretores os zugot, "pares", Shemayah e Avtalyon ${ }^{22}$.

O período da atuação de Hillel, juntamente com a escola do sábio Shamai $^{23}$, marca o surgimento da época dos tanaítas. A novidade inaugurada por esse brilhante sábio, do partido dos fariseus, não foi somente sua dedicação incondicional à Torá, mas a possibilidade de estabelecer regras, relativas ao método aristotélico ${ }^{24}$, no estudo dos textos bíblicos. Tem início o controle racional sobre as interpretações. As sete regras hermenêuticas compiladas por Hillel representam não apenas um momento, mas o modelo de interpretação rabínica praticada diante de qualquer texto bíblico ${ }^{25}$. Posteriormente, as regras passam por um processo de reinterpretação chegando ao conjunto de treze regras, na época de Rabi Yismael ${ }^{26}$ e posteriormente trinta e duas,

${ }^{21}$ Cf. CHARLESWORTH, J. H. e JOHNS, L. (Orgs.); Hillel and Jesus: Comparative Studies of Two Major Religious Leaders, Minneapolis, Fortress Press, 1997, p. 4. As informações biográficas sobre este conceituado mestre da escritura carecem de uniformidade. Miranda e Malca destacam as 316 citações feitas sobre Hillel nas páginas do Talmud, bem como, lendas que se mesclam ao seu alto grau de importância no mundo intelectual da época. Fala-se, até, que teria vivido 120 anos, divididos em três fases distintas: quarenta anos em Babilônia, quarenta como estudante em Jerusalém e outros quarenta na qualidade de patriarca em Jerusalém. Cf. DE MIRANDA, E. E. e MALCA, J. M. S., Sábios fariseus: reparar uma injustiça, op. cit., p.121.

${ }^{22}$ Inúmeras passagens do Talmud anotam o amor incondicional no estudo da Torá demonstrado por Hillel. Cf. HADAS-LEBEL, M., Hillel: un sage au temps de Jésus, op. cit. p. 28; FRIEMAN, S., Who `s who in the Talmud, op. cit., pp. 163-165. As duplas de sábios marcam um período peculiar no cuidado das tradições. Fala-se que um estabelecia-se como nassi, "presidente", enquanto o outro ocupava a cadeira de av bet din, "presidente do tribunal". Embora sendo poucas as informações sobre a função dos pares, sabe-se que atingiram um elevado grau de reconhecimento e admiração, junto à população, após o ano 104. Cf. STEINSALTZ, A., Introduction au Talmud, Paris, Albin Michel, 1987, p. 32.

23 "Estes fariseus foram os dois últimos e mais ilustres dos cinco "pares", mestres fariseus que trabalharam em duplas, como presidente e vice-presidente do San'hedrin". Cf. DE MIRANDA, E. E., e MALCA, J. M. S., Sábios fariseus: reparar uma injustiça, op. cit. p. 122.

${ }^{24}$ Cf. WIGODER, G. (Ed.), Hillel. In: $D E d J$, Paris, Cerf/Robert Laffont, 1996, p. 470.

${ }^{25}$ Passeto destaca o uso feito pela geração apostólica das regras de Hillel no ato de interpretação das escrituras. "Constatamos que o Novo Testamento, formando parte da tradição oral de Israel e a literatura cristã dos primeiros séculos, são testemunhos da oralidade de Israel e que mais tarde passam a serem escritos”. PASSETO, E., La influencia de la tradicion oral de Israel en la tradicion cristiana. In: El Olivo, XIX, 42, 1995, pp. 7-20.

${ }^{26}$ Rabi Yismael (ben Elisha) foi uma grande personalidade na história da exegese bíblica. Atuou na terceira geração do tanaítas, tendo mantido inúmeros debates com R. Akiva, no cenário da hermenêutica. Cf. STRACK, H. L. e STEMBERGER, G., Introduccion a la literatura talmúdica y midrásica, Valencia, Institución S. Jerónimo para la investigación bíblica, 1988, p. 49; FRIEMAN, S., Who's Who in the Talmud, London, Jason Aronson, 1995, pp. 369-371. 
no período da atuação de Rabi Eliezer ${ }^{27}$. Não é de modo algum uma imposição de método a descoberta de Hillel. Seu mérito está na capacidade de compilação de práticas interpretativas há séculos em uso pelos sábios ${ }^{28}$. Ressalto o uso de tais regras hermenêuticas na interpretação de textos do Antigo e Novo Testamento:

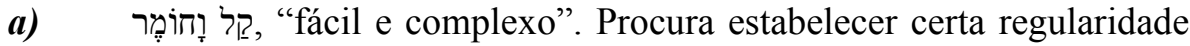
na interpretação dos textos e nas normas estabelecidas partindo sempre do que é mais simples para o que é mais complicado. Um exemplo da regra verifica-se na máxima expressa sobre a quantia que faz parte da פיאה, "respiga", do preceito a ser separado durante a colheita. Nota-se que a narrativa da Mishná faz uma relação que vai do simples para o amplo ao afirmar: "se um recolhe algo do limite e o jogar com os demais já não tem parte dele... o mesmo vale para a rebusca e para o feixe esquecido" (Pea 4,3). Um outro exemplo encontra-se na contenda entre R. Aquiba e R. Eliezer ao determinar quando há ou não cachos de rebusca a serem disponibilizados aos pobres (Pea 7,7).

b) duas narrativas distintas prevalece a mesma interpretação, quando se trata da mesma analogia. Compreende-se que a Bíblia colocou tais expressões similares com o propósito de estabelecer uma reciprocidade entre ambas. Essa regra, porém, deve ser usada com muita propriedade. Ninguém, aleatoriamente, pode-se dar ao privilégio de estabelecer uma gezerah shawah ${ }^{29}$. Um exemplo aplicativo dessa regra está em Pea 6,4, quando está em debate a separação dos feixes que ficam para trás durante a colheita.

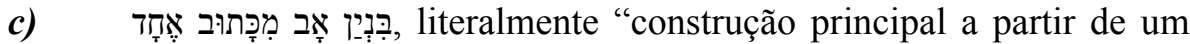
único texto" ${ }^{30}$. Trata-se de vincular a citação feita em um texto a outros textos, uma vez que entre eles são encontrados os mesmos paradigmas ou ter-

\footnotetext{
${ }^{27}$ Rabi Eliezer, conhecido como Eliezer ben José há-Gelilí, atuou na geração de Bar Kokba. Por meio das suas trinta e duas regras se explicam não somente as haggadah, mas toda a Torá. Cf. STRACK, H. L. e STEMBERGER, G., Introduccion a la literatura talmúdica y midrásica, Valencia, Institución S. Jerónimo para la investigación bíblica, 1988, pp. 59-69.

${ }^{28}$ Partindo da época dos pares (200 a.C . - 20 d.C), chegando à geração dos amoraítas (220 500 d.C.), Steinsaltz apresenta um quatro completo das quatro gerações que marcaram a tradição rabínica até a elaboração final do Talmud. Cf. STEINSALTZ, A., The Talmud the Steinsaltz edition: A Reference Guide, New York, Randon House, 1989, p. 30.

${ }^{29} \mathrm{O}$ conceito é amplamente exposto na obra de Strack e Stemberger. Cf. STRACK, H. L. e STEMBERGER, G., Introducción a la literatura talmúdica y midrásica, p. 53. Estas outras regras são também elucidadas por Steinsaltz ao abordar os princípios hermenêuticos do Talmud. Cf. STEINSALTZ, A., The Talmud: the Steinsaltz Edition, p. 150.

${ }^{30}$ Tradução feita considerando as informações de STRACK, H. L. e STEMBERGER, G., op. cit., p. 53.
} 
minologias 31 . "Um texto principal oferece aos demais um caráter comum que os vincula em uma só família"32.

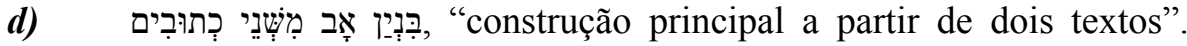
Verifica-se esta regra quando uma conduta é definida como senso comum. O que recebe uma validade em um determinado texto, pode ser semelhante em outros textos. Um nítido exemplo é a defesa sempre incondicional do órfão, do estrangeiro e da viúva nas seis narrativas do livro do Deuteronômio: $10,17-18 ; 14,28-29 ; 16,10-14 ; 24,17-21 ; 26,12-15 ; 27,11-26$. No conjunto dos doze textos mishnáicos o nível de preocupação com os pobres se repete (Pea 4,3. 6,4. 7,7; Msh 5,10; Meg 2,5; Ned 11,3. BM 9,13).

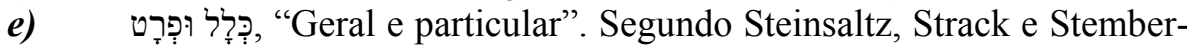
ger esta regra de Hillel foi detalhada em oito princípios hermenêuticos por R. Yismael $^{33}$. Estabeleceu-se um processo capaz de levar ao pleno conhecimento das afirmações presentes nos textos bíblicos, relacionando o geral ao particular e o particular ao geral. A existência de algo válido para todos relaciona-se, inevitavelmente, com o particular. $O$ geral não existe a não ser numa realidade particular e vice-versa. Tal eficácia pode ser exemplificada pelo tratado Shebi 7,1 ao argumentar sobre os produtos sujeitos à lei do sétimo ano: "Em relação ao ano sétimo se estabeleceu uma regra geral: tudo o que é comestível para o homem ou para os animais, as espécies dos tingidores e o que não se conserva na terra, ficam sujeitos às regras do ano sétimo". Tal afirmação envolve também as pequenas hortaliças selvagens utilizadas no trabalho de tingir as roupas.

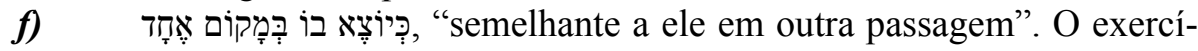
cio de buscar compreender um determinado texto pode ser feito tendo como princípio um texto mais elucidativo, mais claro, mais compreensível. O que é mais evidente pode ajudar na compreensão de textos quase sempre ininteligíveis, num primeiro momento ${ }^{34}$. Em BM 9,13 é refletido os inúmeros tipos de comportamento, entre credor e devedor, quando chega o momento de cobrar uma respectiva dívida. Nota-se que ao longo da argumentação surgem vários exemplos a serem evitados na finalidade de não violar um preceito negativo. $\mathrm{O}$ credor não pode apropriar-se de um bem sem o consentimento

\footnotetext{
${ }^{31}$ Steinsaltz ressalta a existência de três tipos de binyan $a b$ : a) o que nós encontramos quando olhamos para...?"; b) analogia construída a parti de um só verso; c) analogia construída com base em dois versos. CF. STEINSALTZ, A., op. cit., p. 149.

${ }^{32}$ Cf. STRACK, H. L. e STEMBERGER, G., op. cit., p. 53.

${ }^{33}$ Cf. Ibidem, pp. 53-54.

${ }^{34} \mathrm{Um}$ exemplo poder ser compreendido diante da prosperidade firmada com Abraão (Gn 12,3). Trata-se de um elemento central na pregação paulina, ao garantir aos pagãos a salvação por meio da justificação pela fé $(\mathrm{Gl} 3,8.16)$. Cf. PASSETO, E., La influencia de la tradición oral de Israel en la tradición cristiana, op. cit., p. 12.
} 
do Tribunal. A máxima é detalhada ao declarar que o credor não pode aproveitar da situação apropriando-se de meios ligados à produção, e aos afazares do dia-a-dia, como: arado, moinho, colchão e utensílios domésticos.

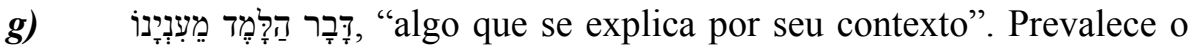
contexto, a realidade como elemento primordial na interpretação de um determinado texto. Há uma evidência nessa regra. É preciso compreender o contexto para se ter a exata interpretação, imposta pelo texto ou realidade em questão. Saber quando se está ou não diante de uma quantia a ser disponibilizada aos pobres, durante a colheita, exige saber o modo e local onde começou a recolher os produtos do campo (Pea 6,4).

Estar o mais próximo do texto bíblico foi a preocupação dos sábios na aplicação e entendimento dos conceitos halakhicos. Desde o momento em que Esdras empenhou-se, com todo o seu coração, para entender, praticar e ensinar a Torá (Cf. Esd 7,10), os sábios vêem nele a função de sua existência: compreender e não medir esforços para explicar e viver segundo os projetos da Torá. Não há outra primazia junto aos sábios que não seja o bom exercício diante da Torá. A primazia da Torá se impõe como um princípio natural. $\mathrm{O}$ que não é compreendido num primeiro contato requererá um exercício com base no midrash - interpretação e comentário, posterior, dos textos bíblicos. Prevalece uma interpretação literal da escritura que, sempre, acena para um gesto concreto, como as normas expressas pela Mishná.

\section{A defesa dos pobres em quatro tratados da Mishná}

O tema sobre a agricultura inaugura a primeira ordem da Mishná que, segundo comentário de Maimônides, é essencial à existência humana, pois sem alimento o homem é incapaz de viver e de servir a Deus ${ }^{35}$. Nessa ordem, זרעים, "sementes", seis tratados encontram suas justificativas na utilização de textos provenientes do livro do Deuteronômio, aqui analisados na seguinte sequência: Pe'ah 4,3; 6,4; 7,7; Dem 1,2; Shebi 7,1 e MSh 5,10. Nota-se que todos os seis capítulos abordam o tema da colheita e a obrigatoriedade de disponibilizar parte da quantia recolhida às pessoas ou grupos necessitados.

\footnotetext{
${ }^{35}$ Cf. WIGODER, G. Sementes. In: DEdJ, p. 1103.

${ }^{36}$ Nesta parte do trabalho, os conceitos provenientes da דִ דָ "Leis" não estão vocalizados, uma vez que utilizamos uma edição da Mishná sem os sinais massoretas.
} 


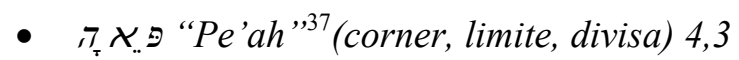

Se alguém recolhe algo (dos frutos do preceito) do limite (de teu campo) e o jogar com os demais já não tem parte nela; porém se jogar-se sobre eles, e estender seu manto se o obriga a tirá-lo dali. O mesmo vale para a rebusca, e para o feixe esquecido ${ }^{38}$.

No versículo, prevalece um vocabulário predominantemente punitivo. Está em debate o recolhimento dos frutos, feito não pelo proprietário, nos limites do seu campo, mas por um pobre que tem a intenção de fraudar o proprietário no momento em que este colhe parte do produto disponibilizado no campo, desvirtuando completamente os preceitos. Identificado o sujeito e o verbo na narrativa, percebe-se a quem a Mishná direciona a repreensão. Os pobres acorriam para fazer o pe'ah em sistema de pilhagem. Cada qual era responsável pelo seu "monte", ajuntado em determinados locais disponíveis no campo.

Seguindo a argumentação de Roth, o sujeito da frase é um "dos mais pobres" que está colhendo o pe`ah deixado por um agricultor. Vale ressaltar que certas pessoas ao colherem uma determinada quantia disponibilizada, segundo a Torá, nem sempre usavam de honestidade ${ }^{39}$. O motivo da repreensão expressa na frase visa alertar uma possível fraude. Caso um pobre esteja recolhendo sua parte do pe'ah e venha a juntar essa quantia às outras que não foram por ele recolhidas ou que pertençam ao proprietário ou a algum de seus companheiros, ele não possuirá parte no montante recolhido. Afinal, seu desejo é de apossar-se de certa quantidade de produtos que não lhe pertencem. Verifica-se a idéia de aproveitar-se de uma situação, por demais corriqueira, e roubar parte de um produto alheio. Percebe-se, nitidamente, o desejo denunciativo, diante de uma atitude não lícita. Um pobre aproveita a situação da respiga para cometer um saque. Nessa situação, a Mishná é clara ao acenar que o pobre que respiga "já não tem parte nela", pois ela foi tirada da

\footnotetext{
${ }^{37}$ Todos os textos da Mishná utilizados no estudo do doze versículo, neste capítulo, foram encontrados na edição eletrônica, disponível em: http://kodesh.snunit.k12.il/. Na edição hebraica: מאגר ספרות הקודש. Acessado pela primeira vez em out. de 2008.

${ }^{38}$ Cf. Dt 24,19-21.

39 "Os tribunais tem o direito de privar alguém de fazer a respiga, a fim de impor a obediencia à lei”. ROTH, R. S., Shiurim Pe'ah. Disponível em:

$<$ http://www.bmv.org.il/Shiurim/pe ah/peah039.html>. Acesso em: 06/04/2009.
} 
parte não estabelecida pelo preceito. Não se pode violar a quantia estabelecida no preceito פיאה.

$\mathrm{Na}$ norma, prevalece o desejo de realizar a justiça. A porção isenta do preceito - leia-se, הפיאה, "o pe'ah" - deve vigorar mediante o esforço do trabalho honesto. Tal aspecto é destaque ao relacionar os frutos recolhidos

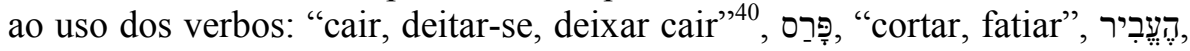
"transferir, remover". Não há meio de burlar o preceito imposto à colheita.

É intencional que a Mishná tenha relacionado a colheita dos frutos à prática que legitima os grupos desfavorecidos de usufruírem do preceito determinado. Não se deve, porém, em nenhuma instância, praticar a violação do preceito, segundo argumento exposto na Mishná: “o mesmo vale para a rebusca e feixe".

Nota-se que ocorre uma mescla da linguagem deuteronômica e a linguagem normativa dos tratados. Um comportamento injusto - nesse caso a violação do preceito - não se pode transferir para as demais instâncias comunitárias. Há um rigor estabelecido pela Torá normatizando toda e qualquer relação social. De Miranda e Malca destacam o posicionamento social e coletivo dos sábios diante da situação da pobreza:

"Estender a tzedaká aos pobres com todo o coração tinha a significação intrínseca de um ato de virtude. Daí ter-se desenvolvido o axioma que, se os ricos fossem realmente honestos e tementes a Deus, distribuiriam prazerosamente a riqueza que retinham em custódia de Deus entre os inúmeros credores de Deus - os pobres, os doentes, os desamparados, os necessitados etc." ${ }^{41}$.

Os sábios visam corrigir uma prática de injustiça, de violação do direito em curso ao afirmar: "já não tem parte nele" e "se o obriga a tirá-lo dali". Na narrativa em questão, os sábios acenam à primazia e autonomia da Torá e, somente com base em seus arcabouços, é possível reconciliar os interesses individuais e coletivos, superando conflitos em vista do bem comum. Para os sábios, a luta para impor a primazia da Torá era, sobretudo, uma missão ética.

Com base na narrativa deuteronômica que garante aos pobres o direito de respigar parte dos produtos deixados no campo, a Mishná ousa denunciar pessoas, entre o grupo dos respigadores, que se apossavam, de modo fraudulento, dos produtos recolhidos e pertencentes a outras pessoas que se encon-

${ }^{40}$ Cf. JASTROW, M., Dictionary of Talmud Babli, Yerushalmi, Midrashic Literature, and Targumim, p. 924.

${ }^{41}$ Cf. DE MIRANDA, E. E., e MALCA, J. M. S., Sábios fariseus: reparar uma injustiça, p. 95. 
travam na mesma condição social. A denúncia é legitima, pois não se pode apoiar-se num preceito divino e fazer dele ocasião de legitimar a desigualdade entre pessoas.

- דמאי "Demay" $1,2^{43}$

Aos produtos do dízimo duvidoso não se aplica a lei do quinto nem da remoção, ${ }^{44}$ podem ser comidos por um que está de luto, ${ }^{45}$ pode-se introduzir em Jerusalém e tirá-los dali. Se, no caminho, se estraga uma pequena quantidade, (não importa); pode-se dar a uma pessoa não instruída, mas haverá de comer o equivalente, (o preço do resgate) pode ser convertido (em dinheiro) de uso comum: prata por prata, dinheiro por cobre, prata por cobre e cobre por frutos, contanto que alguém volte para resgatar os frutos. Esta é a opinião de R. Meir. Os sábios afirmam que os frutos tem que ser levados a Jerusalém e ali, devem ser consumidos.

No estudo e na interpretação das normas estabelecidas nos textos de $\mathrm{Nm} 18$ e Lv 22, os sábios construíram uma jurisprudência relativa aos produtos produzidos por pessoas tidas como incultas, identificadas como "povo da terra" 46 e reconhecidas como negligentes na atribuição do dízimo sobre o resultado da colheita. Ao abordar o tema, procuram responder o que fazer quando se está de posse de um bem ou produto de procedência desconhecida, dos quais não há certeza de que foram recolhidos os respectivos dízimos.

\footnotetext{
${ }^{42}$ A Mishná abre um parágrafo sobre produtos de origem desconhecida. Literalmente, a palavra דמאי significa "dúvida". Cf. STEINSALTZ, A., The Talmud: the Steinsaltz edition, p. 179; DEdJ, p. 270.

${ }^{43} \mathrm{Cf}$. <http://kodesh.snunit.k12.il/b/h/h13.htm>, edição eletrônica, acessado em 29/12/2008.

${ }^{44}$ Cf. Dt 26,13.

${ }^{45}$ Cf. Dt 26,14 .

46 “Quem é um am há-arets? Aquele que não come do alimento não consagrado em estado de pureza levítica - esta é a opinião de R. Meir. Mas os sábios dizem: seja quem for que não separa corretamente o dízimo de sua produção...aquele que não recita o Shema - pela manhã e a tarde - é a opinião de R. Eliezer. R. Yehoshua diz: aquele que não coloca os tefillin. Ben Azzai declara: aquele que não tem mezuza à sua porta e não tem franjas em sua vestimenta. R. Yonathan bar Yossef é da opinião que seja quem for que tem filhos e não os faz estudar a Torá. Outros dizem: mesmo se um indivíduo estudou a Escritura e a Mishná, mas se ele não freqüenta os eruditos, hão de considerá-lo como um am há-arets”. Cf. URBACH, E. E., Les sages d'Israël: conceptions et croyances des maîtres du Talmud, p. 652.
} 
A Mishná apresenta uma norma, considerando as inúmeras leis bíblicas relacionadas aos produtos do campo e à série de dízimos neles embutidos ${ }^{47}$.

As ordens na atribuição do dízimo, segundo Valle, seguiam estes critérios:

\begin{abstract}
"Uma vez descontada a oferenda e o primeiro dízimo, do restante se separava no primeiro, segundo, quarto e quinto ano do sétimo ano outro dízimo (=segundo dízimo), que o proprietário devia levar a Jerusalém e consumi-lo ali. Para evitar os contratempos de transporte se permitia vendê-lo na província e aplicar o equivalente (mas um quinto do seu valor) na aquisição de alimentos em Jerusalém onde deviam ser consumidos. No terceiro e sexto do sétimo ano, este dízimo era entregue aos pobres (Dt 14,22-29; 26,12-15) e, por isso, era chamado dízimo dos pobres" $"$.
\end{abstract}

A Mishná procura resolver qual deve ser o comportamento diante de um produto suspeito de não ter passado pelas exigências de recolhimento das respectivas cifras dos dízimos. Quais são e em que consistem a "lei do quinto" e da "remoção", uma vez que está evidente, segundo a lei, que parte do dízimo deve ser consumido em espécie na cidade de Jerusalém?

A resposta deve ser compreendida por um aprimorado sistema de recolhimento e fiscalização posto em prática pelos sacerdotes. Há um sistema rígido de lealdade ao Senhor (Dt 13,1). Ao apresentar-se como Deus único e realizador de inúmeras obras em favor de seu povo escolhido, Ele passa a ser a garantia de prosperidade e segurança. Não há outro Deus capaz de garantir a aliança firmada. Este modo de pensar a relação Deus e Povo é levado às últimas consequências no Código do Deuteronômio, ao fazer a releitura dos temas já apresentados em Ex 20,22-23,33. Nada mais justo do que enfatizar a intimidade feita por meio de uma aliança entre YHWH e seu povo, Israel. Os textos, mais do que realçar a aliança contraída com essa divindade, visam destacar a lealdade e exclusividade a ele prestada. Ao associar o cumprimento do recolhimento dos dízimos à vontade de YHWH, forjou-se, sim, um arcabouço de idéias infindáveis ${ }^{49}$.

\footnotetext{
${ }^{47} \mathrm{Na}$ época do Segundo Templo, "o agricultor era obrigado a separar a quinta parte de sua produção agrícola que ele "ofertava" aos sacerdotes uma décima parte do restante, como primeiro dízimo. Cf. DEdJ, p. 270.

${ }^{48}$ Cf. DEL VALLE C. (org.), La Mishna, p. 67.

${ }^{49}$ Quanto à quantidade a ser oferecida no pagamento do dízimo há inúmeras abordagens. Cf. ZABATIERO, J. P. T., Tempo e espaço sagrados em Dt 12,1-17,13, p. 137-142.
} 
Há de se ter clareza de que a tributação do dízimo sobre os produtos do campo ocorria todos os anos. Durante o primeiro, segundo, quarto e quinto ano, tempo que compõem o conhecido ciclo da שמיטה, os moradores do país eram obrigados a realizar, assiduamente, o pagamento do שעיטה segundo dízimo. Esses produtos ou a sua soma equivalente em dinheiro, deveriam ser levados a Jerusalém e ali consumidos. O מעשר ראשון ou primeiro dízimo, seguia as prescrições elencadas em Nm 18,21.24, sendo destinado aos levitas. No terceiro e sexto ano, do período da Shmîtah ou período do ano sabático, a soma dos dízimos era destinada à população dos desfavorecidos economicamente, aos merecedores do ou dízimo dos pobres ${ }^{52}$ (Dt $14,28-29 ; 26,12)^{53}$.

Os autores da Mishná, diante dos produtos reconhecidos na categoria "duvidoso", optam por isentar o proprietário de uma série de normas. A primeira refere-se ao ato de efetuar o pagamento, no quinto ano, ficando, deste modo, isento do segundo dízimo. Fica também dispensado de levá-lo, em mercadoria ou em espécie monetária, a Jerusalém e lá encontrar seu destino final. Uma terceira isenção, proveniente de um דמאי, privilegia a pessoa em estado de luto, a quem é facultado o consumo de tal quantia.

Ao comentar o conceito técnico de אנינות, "aninut" forma plural de אונן, "onen", corrente na halakhah, Steinsaltz acentua um tempo de "isenção de todo preceito positivo", enquanto perdurar o período de luto ${ }^{54}$. A Mishná quebra esse preceito. Ao declarar ונאכל לאונן, "Podem ser comidos por um que está de luto" os produtos tidos como demay adquirem uma norma especial, podendo ser consumidos, mas na cidade de Jerusalém, conforme a máxima subscrita por R. Meir ${ }^{55}$. Possivelmente, esta parte do segundo dízimo, consumido em Jerusalém, devia coincidir com a época em que os israelitas subiam em direção a cidade de Jerusalém para as festas de peregrinação.

\footnotetext{
${ }^{50}$ Cf. STEINSALTZ, A., The Talmud: the Steinsaltz Edition, p. 222.

${ }^{51}$ Cf. Ibidem, p. 221.

${ }^{52} \mathrm{Cf}$. Ibidem.

${ }^{53} \mathrm{O}$ ato de não disponibilizar os respectivos dízimos e valores correspondente será também denunciado no tratado Abhot 5,9. Ver análise mais adiante, p. 32.

${ }^{54}$ Cf. STEINSALTZ, A., op. cit., p. 162. O período de exéquias envolvia a morte de alguém próximo ao círculo de parentesco em primeiro grau: pai, mãe, irmã, irmão, filho, filha, marido ou esposa. De todo e qualquer mandamento positivo - orar o Shema, uso do tallit, comer carne e beber vinho, comer da oferta do segundo dízimo e comer dos sacrifícios sagrados - a pessoa estava proibida de realizar.

${ }_{55}$ Fala-se que foi o primeiro discípulo de Rabi Ushmael e posteriormente de Rabi Akiva, no período tanaíta. Homem de memória privilegiada, escriba de profissão, deu sequencia aos ensinamentos deixados por seu mestre, Akiva. Seu trabalho foi de fundamental importância ao compilar as tradições orais sendo indispensáveis na redação da Mishná. DE MIRANDA, E. E. e MALCA, J. M. S., Sábios fariseus: reparar uma injustiça, p. 176.
} 
Sendo assim, vê-se que a obrigatoriedade de consumo em Jerusalém servia para a subsistência dos peregrinos nos dias em que perduravam os festejos.

- שביעית "Shebiit" 7,1

Em relação ao ano sétimo se estabeleceu uma regra geral: tudo o que é comestível para o homem ou para os animais, as espécies dos tingidores e o que não se conserva na terra, ficam sujeitos às regras do ano sétimo, como também o dinheiro obtido em sua venda. Estão sujeitos à lei da remoção $0^{57}$, e mesmo o dinheiro obtido em sua venda. Quais são? As folhas de ervas silvestres, as folhas de menta, a escarola, os alhos, a flor- de- leque e a flor-de-leite. E as ervas para o gado? As sarças e os espinhos, espécies que usam os tingidores? Os brotos de anil e do falso açafrão. Eles estão submetidos à lei do sétimo ano, e também o dinheiro obtido em sua venda. Eles estão sujeitos à lei da remoção, o mesmo que o dinheiro obtido em sua venda.

Um grande problema era definir quais os produtos que estão ou não sob as normas estabelecidas no ano sabático. Duas diferentes realidades estão no centro dessa norma posta em prática: o repouso da terra ${ }^{58}$ e a anulação dos casos das dívidas financeiras ${ }^{59}$. A chegada do sétimo ano propiciava uma era de equidade, um recomeçar de novo, entre todos os grupos sociais. Tempo de negação de qualquer experiência acenando concentração de bens e acúmulo de riqueza. Seguindo as orientações vindas da Torá ${ }^{60}$, a "Shebiit", ou ano sabático era o tempo por excelência da reparação das injustiças, da equiparação da concentração de renda oriunda do acúmulo de terras ou cobranças de juros por empréstimos realizados. Refere-se ao período da distribuição de renda àqueles diretamente envolvidos nas tarefas do dia-a-dia: escravos e empregados e um posicionamento objetivo e claro, por parte dos sábios, em motivar o povo a viver sob a soberania de YHWH.

\footnotetext{
${ }^{56} \mathrm{Cf}$. $<$ http://kodesh.snunit.k12.il/b/h/h15.htm>, edição eletrônica, acessado em 29/12/2008.

${ }^{57}$ Cf. Dt 26,13.

${ }^{58}$ Refere-se ao conceito da שמיטת קרקע, "libertação da terra". Todos os produtos devem permanecer no campo e serem consumidos por animais, aves e apanhados por pessoas. Cf. STEINSALTZ, A., The Talmud: the Steinsaltz edition, p. 260.

${ }^{59}$ Refere-se ao conceito da שמיטת כספים, "cancelamento das dívidas financeiras”. Cf. Ibidem, p. 261.

${ }^{60}$ Cf. Ex 23,10-11; Lv 25,2-7; Dt 15,1-6.
} 
O texto diz que todos os produtos da terra, tidos como comestíveis pelos homens e animais, estão sujeitos à lei. O texto da Mishná é explicito: "tudo que é comestível ao homem" e também "e comestível para os animais" está disponibilizado quando da chegada do ano jubilar. Nada deve ficar excluído da lei do sétimo ano, nem mesmo a lei da remissão sobre qualquer produto.

Nada deve deixar de ser considerado no tempo da remissão. Neste aspecto, compreende-se o argumento considerando, até mesmo, as pequenas ervas, ervas selvagens, tidas como insignificantes e utilizadas para o tingimento de roupas, tais como: ervas silvestres, folhas de menta, escalora, alho, flor-de-leque, flor-de-leite, broto de anil, falso açafrão. Tudo deve ser disponibilizado com a chegada do ano sabático.

Há de se freiar os abusos sociais. Esse adendo pode ser considerado pelo uso do termo ביעור "remoção", quatro vezes corrente no versículo. Uma vez que tudo está submetido à lei do ano sabático, também "ficam sujeitos à lei da remoção e mesmo o dinheiro obtido em sua venda". Isto é, a remoção do dízimo dos produtos do ano quarto e sétimo; esse último, coincidindo com o ano jubilar, deve estar sujeito à lei do período sabático. Nada pode escapar da regra máxima com a chegada do ano da remissão ${ }^{62}$. O projeto imposto é fruto da vontade divina. Os argumentos dos sábios encontram eco e credibilidade por serem oriundos do próprio Senhor: "pois se chama remissão para o Senhor" (Dt 15,2).

Os sábios eram profundos conhecedores das inúmeras relações sociais geradoras de injustiças. O posicionamento ético diante de uma situação de injustiça é inquestionável. A primazia volta-se ao ano sabático, princípio e eixo de toda prática na esfera social. Trata-se de uma intervenção por demais ambiciosa por parte dos sábios, mas pautada na instância da Torá, o que lhes dava maior credibilidade e confiabilidade junto às mais diferentes instâncias da esfera social. Não falam em nome próprio, mas sim em nome de YHWH. A base de toda argumentação não é outra se não a realização da vontade e palavra do senhor.

- מעשר שני "Maaser Sheni" 5,10

$\mathrm{Na}$ tarde do último dia se faz a confissão. Qual era a fórmula da confissão? Separei o que é consagrado da minha casa (Dt 26,13), isto é, o segundo dízimo e os

${ }^{61}$ Cf JASTROW, M., Dictionary of the Targumin, the Talmud Babli and Yerushalmi, and the Midrashic Literature, p. 164.

${ }^{62}$ Cf. Dt 15,9 . 
frutos das árvores do quarto ano. Dei-o para o levita (Dt $26,13)$ isto é, o dízimo do levita. Também fiz outra entrega (Dt 26,13). A saber, a oferta e a a oferta do dízimo, Para o estrangeiro, para o órfão e para a viúva (Dt 26,13), Fiz a entrega do dízimo dos pobres o fruto da respiga, o fruto esquecido e o da esquina, ainda que isto não invalidam a onfissão. da minha casa, isto é a massa (devida ao sacerdote).

O vocabulário predominante na perícope é cúltico, com destaque para a oração pronunciada durante o gesto de oferecimento de um sacrifício ou de um dos dízimos prescrito pela Torá. Ao declarar "na tarde do último dia festivo", a Mishná refere-se às orações que acompanhavam a entrega dos dízimos no quarto e sétimo ano, do período sabático ${ }^{63}$.

A fórmula proposta na Mishná tem origem no texto de Dt 26,13-15 $\mathrm{Na}$ sequência, são considarados três diferentes dízimos. A primeira oferta citada é "isto é o segundo dízimo" ofertado "durante o primeiro, segundo, quarto e quinto ano do período sabático" ${ }^{\circ 5}$. Sob essa quantia era determinado seu consumo, quando possível, em Jerusalém, podendo, de acordo com a realidade, ser trocada pela quantia equivalente em dinheiro.

O versículo cita "isto é, o dízimo do levita", conhecido como "primeiro dízimo" "66. Este dízimo inicial era entregue ao levita, após o cumprimento da Teroumah, "oferta" sobre o resultado de toda a colheita. O levita, por sua vez, era obrigado a doar um décimo de todos os dízimos ao sacerdote. Todos os moradores em Israel tinham obrigação de cumprir o preceito, que direcionava um décimo para os sacerdotes.

Um terceiro dízimo era destinado ao estrangeiro, órfão e viúva. Pertencem a esta trilogia os grupos dos pobres, escravos, trabalhadores. O versículo é muito objetivo ao apresentar os destinatários do "dízimo dos pobres". A redação Mishnáica segue paralela ao texto de Dt 24,19.20.21. A realidade da respiga, do esquecimento e do ato da vindima acenam para o cumprimento de todas as normas que não podiam ser negligenciadas pelos agricultores.

Todos os sacrifícios feitos eram seguidos de oração. A "confissão do dízimo", tinha como elemento único a recitação de Dt 26,13-15. Seguindo a

יום טוב O termo, “O grande Festival”, alude à festa da Páscoa. Cf. DEL VALLE, C., La Misna, p.179. O termo pode também referendar as respectivas festas: Shavuot, Rosh HaShanah e Sukkot. Em certos contextos refere-se ao dia do perdão, Yom Kippur.

${ }^{64}$ Cf. M. Msh. 5,12-13.

${ }^{65}$ Cf. STEINSALTZ, A., The Talmud: the Steinsaltz Edition, p. 222.

${ }^{66}$ Um décimo da quantia recebida era entrega pelo levita ao sacerdote. Cf. STEINSALTZ, A., op. cit., p. 221. 
própria Mishná, e apoiado nos comentários de Del Valle e Steinsaltz ${ }^{67}$, a prática de recitar o conteúdo desses versículos foi abolida por ordem de João Hircano (135-104), considerando as inúmeras faltas no ato de cumprir corretamente as prescrições ao disponibilizar a quantia dos respectivos dízimos, segundo a cifra estabelecida.

"O segundo dízimo está destinado à comida, à bebida $\mathrm{e}$ à unção; para comer o que habitualmente se come; para beber, o que realmente se bebe; para usar como unguento, o que habitualmente se usa como unguento" 68 .

Os preceitos referentes ao dízimo exigiam um trabalho, empreendido por parte do doador, e seu gesto é qualificado no momento em que ele a recita manifestando, deste modo, de forma correta, sua confiança na soberania de Deus, atualizada todos os anos, ao cumprir a norma estabelecida. Praticála é reafirmar sua confiança nas bênçãos vinda de Deus, sinônimos de prosperidade na colheita, satisfação em construir uma sociedade de iguais e esperança daquele que crê no amor de Deus. O fiel se vê na qualidade de cumpridor da vontade do Senhor. O próprio Deus o qualifica.

\section{Referências Bibliográficas}

ARTUS, Olivier. Les lois du Pentateuque: Points de repère pour une lecture exégétique et théologique. Paris: Cerf, 2005.

BENNETT, Harold V. Triennial tithes and the underdog: a revisionist reading of Deuteronomy 14,22-29 and 26,12-15. In: BAILEY, R. C. (Org.). Yet with a steady beat: contemporary: U. S. afrocentric biblical Interpretation. Atlanta: Society of Biblical Literatura, pp. 7-18.

BERTRAND, Marianne. L’étranger dans les lois bibliques. In: RIAUD, Jean. (Org.). L 'étranger dans la Bible et ses lectures. Paris: Cerf, 2007, pp. 55-84.

BRIEND, J. Israel y Judá: En los textos del próximo Oriente Antiguo. Navarra: Verbo Divino, 1982.

BRIEND, Jaques, LEBRUN, René e PUECH, Émile. Tratados e Juramentos no Antigo Oriente Próximo. São Paulo: Paulus, 1998.

BOUZON, Emanuel. O Código de Hammurabi. Petrópolis: Vozes, 2001.

${ }^{67}$ Cf. M. Msh 5,15; DEL VALLE, C., La Misna, p.180; STEINSALTZ, A., The Talmud: the Steinsaltz Edition, p. 185.

${ }^{68}$ Cf. M. Msh, 2,1. 
. Contratos Pré-Hammurabianos do Reino de Larsa. Porto Alegre: Edipucrs, 2000.

. Uma Coleção de Direito Babilônico PréHammurabiano. Petrópolis: Vozes, 2001.

CARRIÈRE, Jean-Marie. Le cadre où se forme la décision politique": lecture de Deutéronome 16,18 - 18,22. In: NRT, Bruxelles, n. 121, pp. 529-54, 1999.

CAZELLES, Henri. Droit public dans le Deutéronome. In: LOHFINK, Norbert. Das Deuteronomiun: entstehung, gestalt und botschaft. Leuven, University Press, 1985, pp. 99-106.

CRÜSEMANN, Frank. A. Torá: Teologia e história social da lei do Antigo Testamento. Petrópolis: Vozes, 2002.

EPSZTEIN. Léon. A justiça social no Antigo Oriente Médio e o povo da Bíblia. São Paulo, Paulinas, 1990.

FINKELSTEIN, Israel. e SILBERMAN, Neil Asher. Les rois sacrés de la Bible: À la recherche de David et Salomon. Paris: Bayard, 2006.

FRIEMAN, Shulamis. Who`s Who in the Talmud. New Jersey, Jason Aronson, 1995

GRENZER, Matthias. Análise poética da sociedade: um estudo de Jó 24. São Paulo: Paulinas, 2005.

KRAMER, Pedro. Origem e legislação do deteuronômio: programa de uma sociedade sem empobrecidos e excluídos. São Paulo, Paulinas, 2005.

LENHARDT, Pierre e COLLIN, Matthieu. A Torahh oral dos Fariseus: textos da tradição de Israel. São Paulo, Paulus, 1997.

MANNS, Fréderic. Le Judaisme: Milieu et Mémoire du Nouveau Testament, Jerusalém, Franciscan Priting Press, 1992.

. Un père avait deux fils: Judaïsme et Christianisme em Dialogue. Médiaspaul.

NODET, Étienne; TAYLOR, Justin. Essai sur les Origines du Christianisme. Paris: Cerf, 1998.

PAUL, André. À l'écoute de la Torah: Introduction au Judaïsme. Paris: Cerf. 2000.

PINZETTA, Inácio. Um projeto de defesa aos estrangeiros: a proposta do Deuteronômio. In: Estudos Bíblicos, n. 27, 1990, pp. 27- 35.

REIMER, Haroldo., Um tempo de graça para recomeçar: o ano sabático em Exodo 21,2-11 e Deuteronômio 15,1-18. In: RIBLA 33, 1999, pp. 33-50.

STEINSALTZ, Adin. The Talmud. New York: Random House, 1989.

STRACK, Hermann. L.; STEMBERGER, Günter. Introducción a la Literatura Talmúdica y Midrásica. Valencia: Institución S. Jerónimo para la Investigación Bíblica, 1998. 
VALLE, Carlos Del. La Misna. Salamanca: Sigueme, 1997.

ZABATIERO, Júlio Paulo Tavares. Em busca de uma economia solidária: Dt 14,22-15,23 resistência popular e identidade social. In: EsBi 84, 2004, pp. 9-21.

\section{Resumo}

As declarações conciliares deflagraram um processo de "agiornamento" (atualização) em toda vida eclesial, ainda em curso. O diálogo entre teologia cristã e tradição judaica refez caminhos e acena gestos pastorais e reflexões teológicas que não devem estagnar. O presente texto busca interagir dois importantes universos literários: textos deuteronômicos com normas jurídicas registradas na Mishná, tendo como eixo a defesa do estrangeiro, órfão e viúva. Busca dialogar dois importantes universos jurídicos e certificar a interdependências entre eles.

Palavras-chave: Trilogia Social, Estrangeiro, Órfão, Viúva, Mishná, Sábios de Israel.

\section{Resumé}

Le Concile a déclenché un processus de "agiornamento" (actualisation) dans la vie ecclésiale, toujours en cours. Le dialogue entre la théologie chrétienne et la tradition juive refait chemins et indique réflexion pastorale et théologique qui ne doit pas stagner. Ce texte vise à intégrer deux importants univers littéraires: textes Deutéronomics avec les normes morales inscrites dans la Michnah, considérant la protection des groupes sociaux défavorisés. Cherche à mettre en dialogue deux importantes univers juridiques et certifier les interdépendances entre eux.

Mots-clés: Sociale Trilogie, Étranger, Orphelin, Veuve, Michnah, Sages d'Israël.

Antonio Carlos Frizzo

Vigário na paróquia S. Cruz, Jd. Presidente Dutra na Diocese de Guarulhos Professor de teologia bíblica na Faculdade Dehoniana, Taubaté, São Paulo Participa da equipe de assessores no Centro Bíblico Verbo, São Paulo E-mail: acfrizzo@uol.com.br

Artigo Recebido em 23/09/2010 Artigo Aprovado em 16/11/2010 